\title{
Recent Changes in the Spatial and Temporal Distribution of Salmon Habitat in the North Pacific
}

\author{
Steven T. Lindley, Nathan J. Mantua, Tanya L. Rogers, and Stephan B. Munch \\ Southwest Fisheries Science Center, National Marine Fisheries Service, 110 McAllister Way, Santa Cruz CA 95060, \\ USA
}

Keywords: Pacific salmon, marine heat waves, primary production, mixed-layer properties

As the oceans warm, marine heat waves (MHW) have gained attention. The 2014-2016 MHW in the northeast Pacific, in particular, catalyzed increased interest in the causes and consequences of widespread, intense, and persistent warming. For a few decades now, researchers have recognized correlations between decadal-scale warming and cooling cycles and cycles of salmonid productivity. Generally, warming has negative impacts on salmon stocks from warmer parts of the North Pacific, and positive effects on stocks in colder regions. Thus, the 2014-2016 MHW in the northeast Pacific was an alarming event to fishery managers in the continental USA.

While statistical relationships between SST and salmon population variation are frequently observed, the mechanism linking them are less clear. Warming can impact salmon directly or indirectly. Direct impacts could include behavioral avoidance of temperatures beyond thermal preference and changes in metabolic rate affecting growth and maturation. Indirect effects could occur through impacts on salmon prey. Bottom-up effects of warming are likely dependent on the mechanism of warming and its ecosystem context, which influence the timing, magnitude, and composition of primary and secondary production. Winter mixing resupplies surface waters with nutrients, and spring stratification allows phytoplankton to deplete the nutrients. The cycle of mixing and stratification gives the ocean a memory that can drive intra- and inter-annual production variability in complex ways.

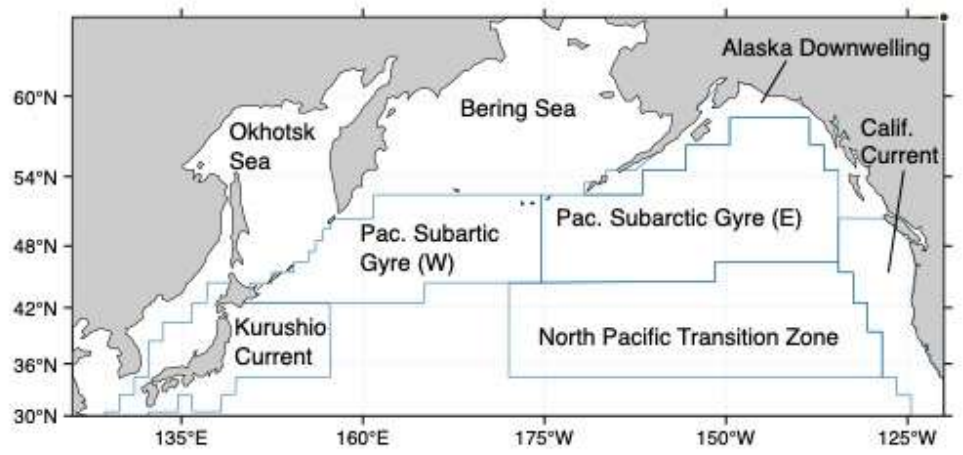

Fig. 1. Large marine ecosystems of the North Pacific, as defined by Longhurst (1998) on the basis of current boundaries and dynamics driving seasonal production regimes.

In this paper, we explore recent trends (2002-2020) in SST (Hadley $1^{\circ}$; Rayner et al. 2003), mixed layer depth (via Argo buoy data; Holte et al. 2017), and primary production (based on ocean color and temperature; Behrenfeld and Falkowski 1997) across ecosystems of the North Pacific; changes in the horizontal extent of thermally-suitable habitat for six species of Pacific salmonids (based on Hadley $1^{\circ}$ SST and species-specific temperature criteria; Abdul-Aziz et al. 2011); and summarize recent changes in salmon production across the north Pacific that may be related to changes in ocean conditions. We summarize information by large marine ecosystems, as defined by Longhurst (1998) and as shown in Fig. 1.

North Pacific ecosystems have shown quite different patterns of variation in mixed layer properties and primary production over the past two decades (Fig. 2). The Bering Sea has exhibited low-frequency variation in SST, with generally warmer-than-average conditions from 2014-2020. From 2018-2020, mixed layer depth experienced episodes of deepening in the winter (January-March) while maintaining warmer-than-average SSTs. Primary production shows no obvious relationship to these changes. The eastern North Pacific Gyre experienced high SSTs in 2014-2016 and late 2018-2020, which followed a relatively cool period from 2006-2013. The warming began in the second half of 2013, with periods of mixed-layer shoaling through 2014, which also corresponded to periods of higher-than-normal primary production. The western portion of the North Pacific Gyre did not exhibit the same low-frequency variation in SST but did experience a period of warming in 2013 and 2014, with slight shoaling of the thermocline evident and little deviation of primary production from its usual seasonal pattern. Both the Alaskan Downwelling and California Current regions experienced warmer-than-usual SSTs in 
2014-2016 and 2019. As in the eastern Pacific Subarctic Gyre, the onset of the MHW in the California Current was associated with a shallower mixed layer depth, a pattern shared with the Alaskan Downwelling region to a lesser extent. In all three regions, the initial period of warming was associated with higher primary production, but while the warming persisted, the higher production did not. The Sea of Okhotsk, like the eastern subarctic Pacific, showed clear interdecadal variability, but of opposite sign, and has generally cooled over the past two decades.

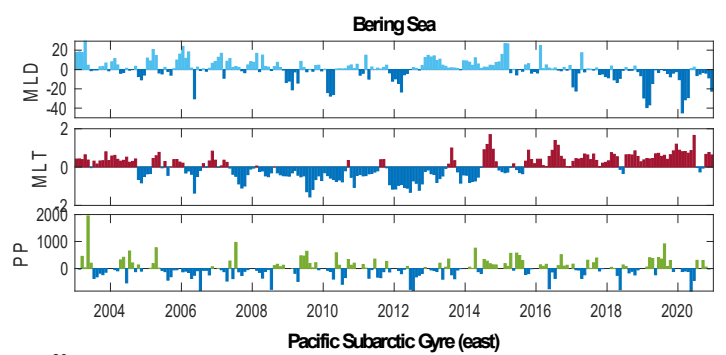

Fig. 2. Mixed layer depth, temperature and primary production anomalies in North Pacific ecosystems.
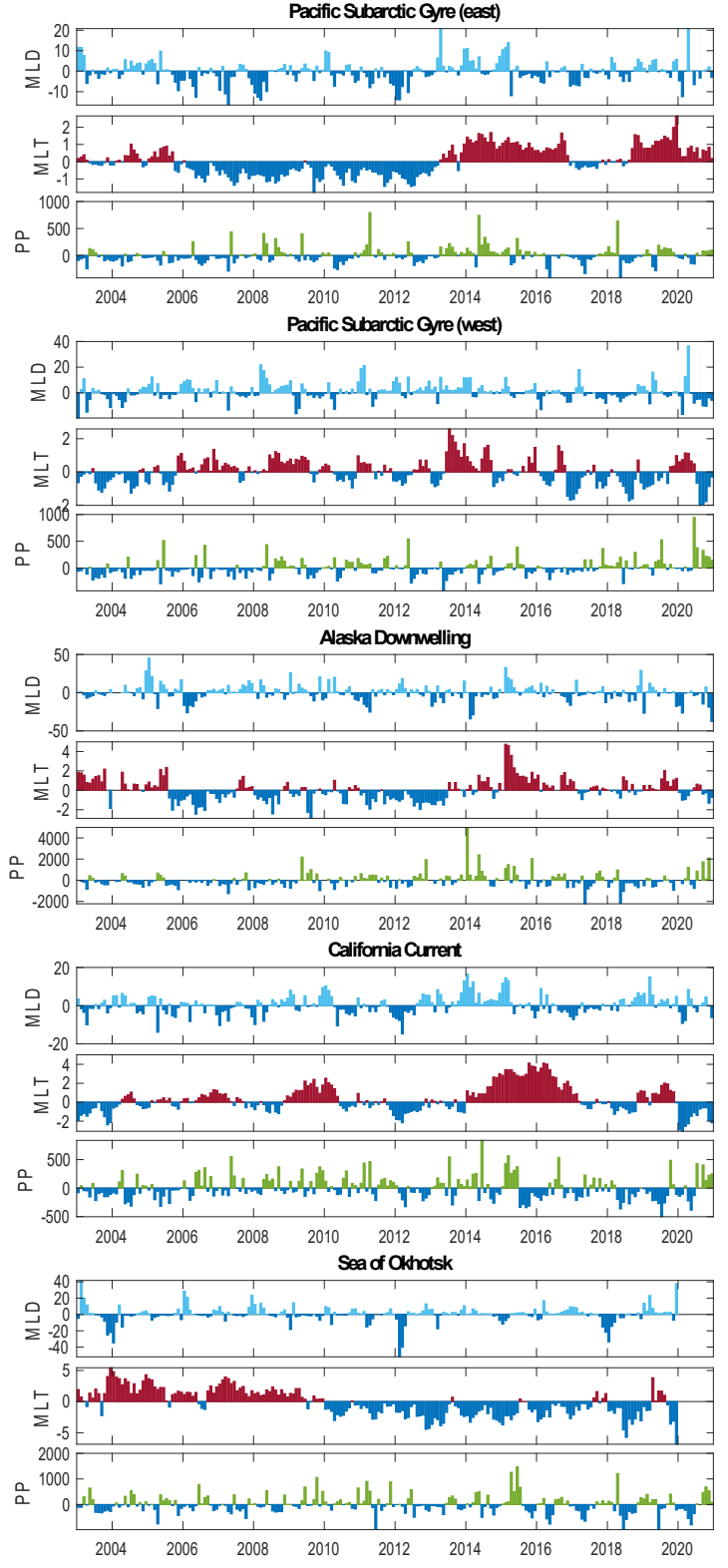

We used convergent cross mapping (CCM) to evaluate whether physical variable anomalies (mixed layer depth, temperature, and salinity) cause anomalies in primary production. To address the causal relationship between 
two time series, CCM reconstructs system states from the two time series variables and then quantifies the correspondence between them using nearest neighbor forecasting (Ye et al. 2015). If variable $X$ drives variable $Y$, then information about $X$ can be obtained from $Y$, establishing causality (Sugihara et al. 2012). Primary production anomalies were weakly to moderately coupled to anomalies in physical variables, with linkages most typically to adjacent regions at lags of several months. The California Current and North Pacific Transition Zone are exceptions: productivity is related to temperature in those areas nine months previously.

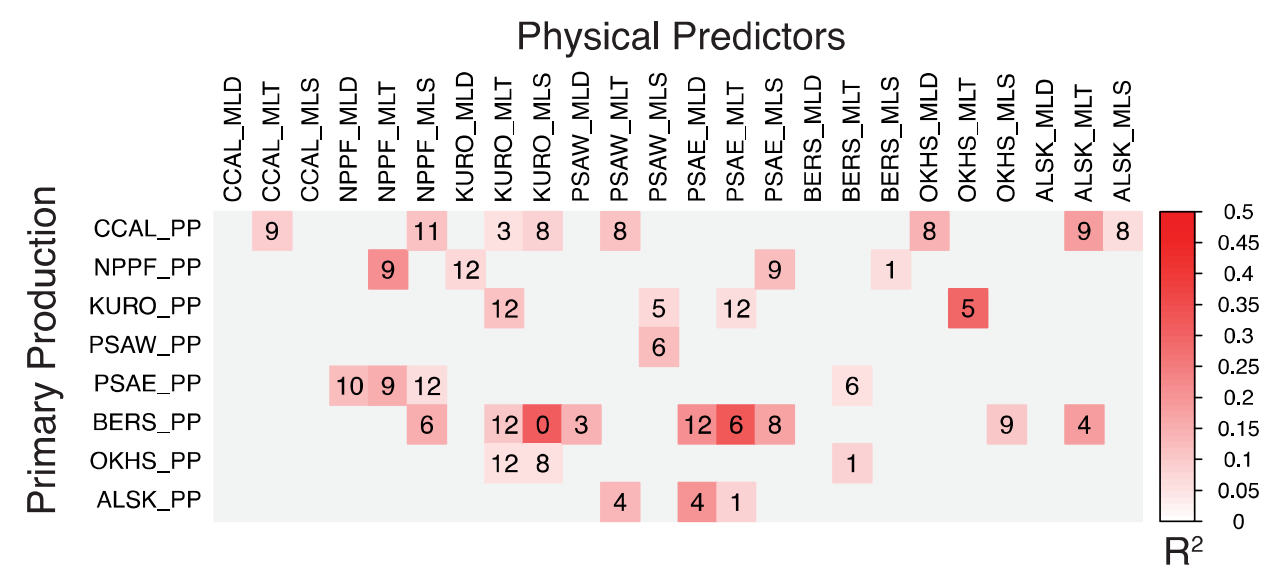

Fig. 3. Relationship between primary production and mixed layer properties. Color intensity indicates strength of relationship; number is the lag (in months) with the strongest relationship. Abbreviations: $\mathrm{CCAL}=\mathrm{California}$ Current; NPPF = North Pacific Transition Zone; KURO = Kuroshio Current; PSAW = Pacific Subarctic Gyre (west); PSAE = Pacific Subarctic Gyre (east); BERS = Bering Sea; OKHS = Okhotsk Sea; ALSK = Alaskan Coastal Downwelling; $\mathrm{PP}=$ primary production; $\mathrm{MLD}=$ mixed layer depth; $\mathrm{MLT}=$ mixed layer temperature; MLS = mixed layer salinity. Ecoregion boundaries are defined by Longhurst (1998), but his BERS region is split into the Bering and Okhotsk seas.
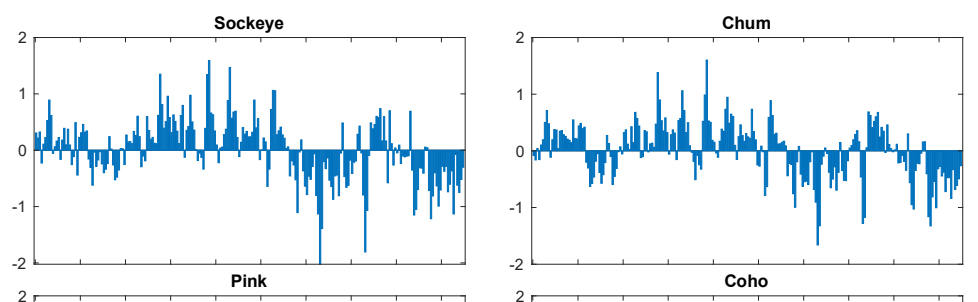

Fig. 4. Anomalies in aerial extent of thermally suitable sea surface temperatures (in millions of $\mathrm{km}^{-2}$ ).
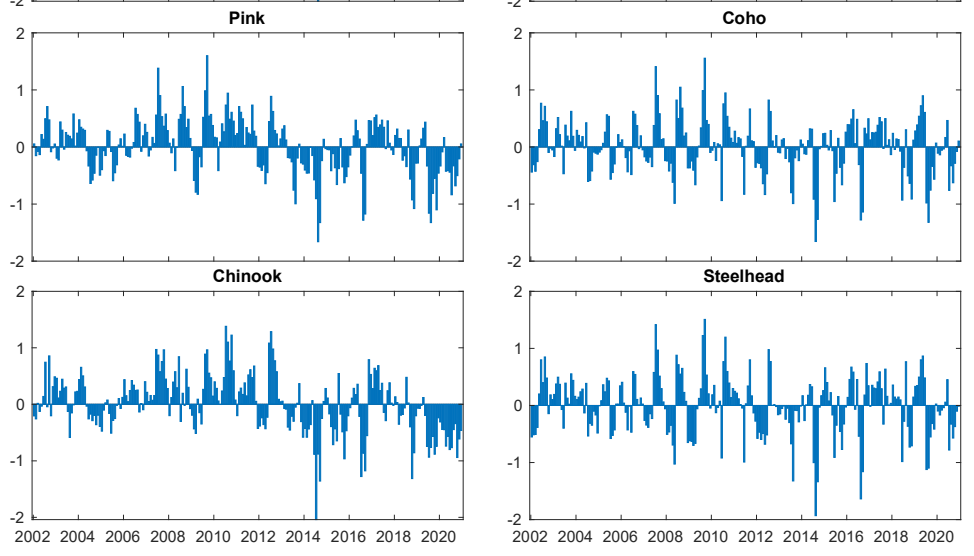

The marine heat waves in 2014-2016 and 2019 reduced the area of suitable SSTs in the north Pacific by up to $2 \times 10^{6} \mathrm{~km}^{2}$ compared to average months for steelhead, Chinook, and sockeye salmon, and somewhat lesser amounts for other species (Fig. 4). During the summers of 2014-2016, suitable SSTs for Chinook were almost nonexistent, limited to small portions of the Bering Sea and Sea of Okhotsk (Fig. 5). The Bering Sea remained hospitable for sockeye and steelhead in this period, although suitable areas in the eastern North Pacific subarctic gyre contracted towards the Aleutian Islands. 

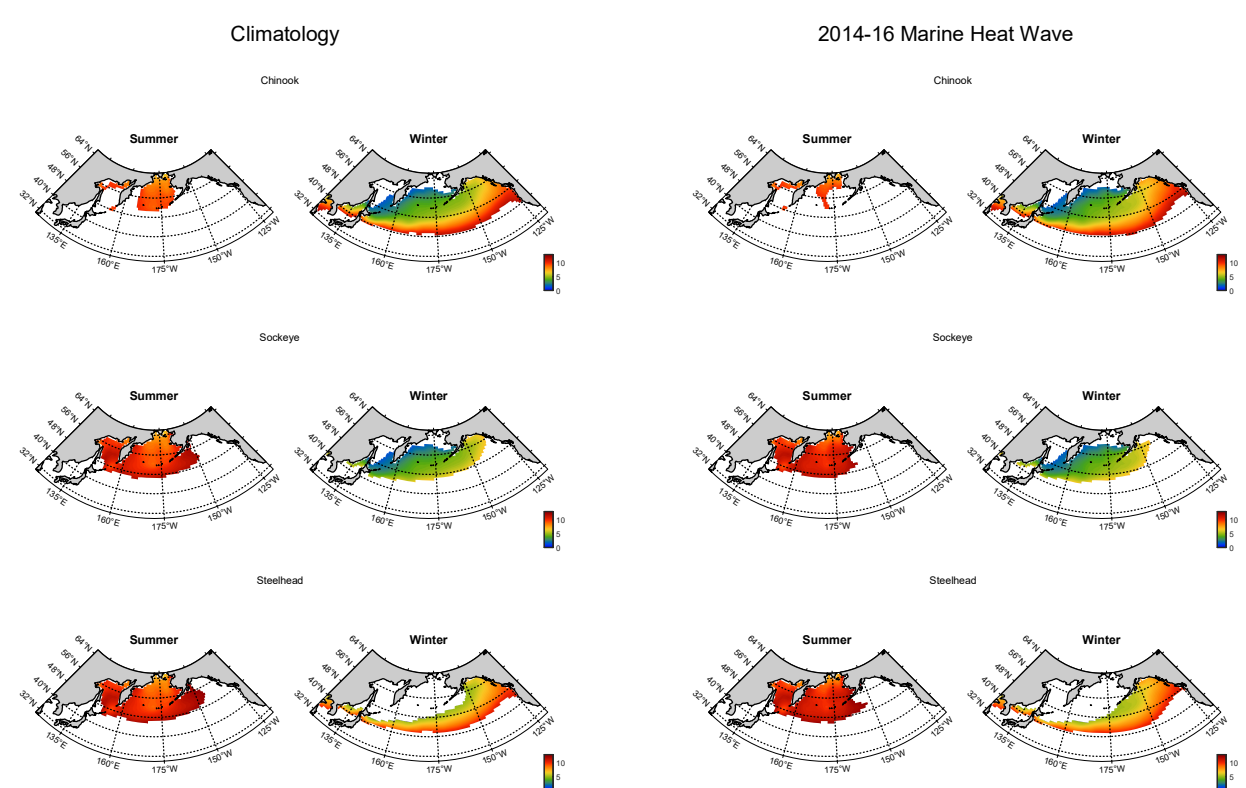

Steelhead

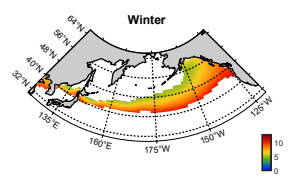

Fig. 5. Distribution of suitable SSTs for Chinook salmon, sockeye salmon and steelhead in the North Pacific under climatological conditions and during the 20142016 marine heat wave. Seasonal thermal suitability criteria are taken from Abdul-Aziz et al. (2011).

Table 1. Ocean temperatures and observations of unusual salmon fishery conditions aligned by ocean entry year for the dominant year classes of the affected species for all entries except 2014 US Fraser River Sockeye Fishery Disaster Determination. In that case, return year 2014 is aligned with marine heatwave year 2014 to reflect the impact of warm SSTs on the adult migration route. Russian pink salmon harvest data from npafc.org; Chignik harvest and escapement from adfg.alaska.gov; US Federal Fishery Disaster Determinations (FDDs) from https://www.fisheries.noaa.gov/national/funding-andfinancial-services/fishery-disaster-determinations; BC fishery information from Pacific Salmon Commission Reports (psc.org). Positive responses are in dark green text and negative responses are in red text.

Notable Salmon Observations in Years Following

\begin{tabular}{|c|c|c|c|}
\hline \multirow[b]{2}{*}{$\begin{array}{l}\text { Ocean Climate } \\
\text { Year }\end{array}$} & \multirow[b]{2}{*}{ Climate Conditions } & \\
\hline & & +1 & +2 \\
\hline 2014 & $\begin{array}{l}\text { Extreme warm SST anomalies in } \\
\text { the Bering Sea and Gulf of } \\
\text { Alaska and NE Pacific }\end{array}$ & $\begin{array}{l}\text { Pink salmon harvest in Russia-368.7 } \\
\text { million. Washington State coho and } \\
\text { pink salmon, tribal fishery FDD }\end{array}$ & $\begin{array}{l}\text { Near-historical high Bristol Bay } \\
\text { sockeye harvest and returns ( }>50 \\
\text { million); Record high Prince William } \\
\text { Sound pink salmon harvest ( } 98 \\
\text { million). Extremely low Fraser River } \\
\text { sockeye returns }\end{array}$ \\
\hline 2015 & $\begin{array}{l}\text { Extreme warm SST anomalies in } \\
\text { the Gulf of Alaska, warm in the } \\
\text { Bering Sea and NE Pacific }\end{array}$ & $\begin{array}{l}\text { Pink salmon harvest in Russia- } 439 \\
\text { million. Gulf of Alaska pink salmon } \\
\text { FDD ( } 13.3 \text { million harvest in Prince } \\
\text { William Sound) }\end{array}$ & $\begin{array}{l}\text { Near-historical high Bristol Bay } \\
\text { sockeye harvest and returns ( }>50 \\
\text { million). Extremely low Fraser River } \\
\text { Sockeye run size; Extreme low } \\
\text { steelhead returns to the Thompson } \\
\text { and Chilcotin Rivers }\end{array}$ \\
\hline 2016 & $\begin{array}{l}\text { Extreme warm SST anomalies in } \\
\text { the Bering Sea, warm in the Gulf } \\
\text { of Alaska and western Subarctic } \\
\text { North Pacific }\end{array}$ & $\begin{array}{l}2017 \text { pink salmon harvest in Russia- } \\
353 \text { million }\end{array}$ & $\begin{array}{l}\text { Near-historical high Bristol Bay } \\
\text { sockeye harvest and returns ( }>50 \\
\text { million). Chignik sockeye FDD; } \\
\text { many GoA sockeye stocks had poor } \\
\text { returns; Fraser River "cycleyear" } \\
\text { sockeye harvest and returns well } \\
\text { below average }\end{array}$ \\
\hline 2017 & $\begin{array}{l}\text { Near normal SSTs in the Gulf of } \\
\text { Alaska, warm in the Bering Sea }\end{array}$ & $\begin{array}{l}\text { Record high pink salmon harvest in } \\
\text { Russia- } 676 \text { million. Lowest pink } \\
\text { salmon returns to SE Alaska since } 1980\end{array}$ & $\begin{array}{l}\text { Near-historical high Bristol Bay } \\
\text { sockeye harvest and returns ( } 56.5 \\
\text { million wild sockeye). Chignik } \\
\text { sockeye harvest below average, } \\
\text { barely met escapement goals; } 2019 \\
\text { Fraser River sockeye fishery closed; } \\
\text { extreme low run-size }(500,000)\end{array}$ \\
\hline 2018 & $\begin{array}{l}\text { Extreme warm SST anomalies in } \\
\text { northern Bering Sea and Chukchi } \\
\text { Sea, warm throughout the Gulf of } \\
\text { Alaska }\end{array}$ & $\begin{array}{l}\text { High pink salmon harvest and returns } \\
\text { to Russia }\end{array}$ & $\begin{array}{l}\text { Near-historical high Bristol Bay } \\
\text { sockeye harvest and returns ( } 58.2 \\
\text { million wild sockeye). Extremely } \\
\text { low Copper River sockeye run-size; } \\
\text { Fraser River sockeye record-low run- } \\
\text { size of } 300,000\end{array}$ \\
\hline
\end{tabular}


Salmon stocks around the North Pacific have responded to the recent MHW in divergent ways (summarized in Table 1). Those originating from North America and entering the Gulf of Alaska (eastern Subarctic Gyre and Alaskan Downwelling regions) have fared poorly, while those utilizing the Bering Sea and Sea of Okhotsk have mostly seen increases. The general patterns are consistent with the idea of the effect of warming being dependent on its relation to thermal optima - warming above the optima is detrimental, while warming below it is beneficial. These effects can be modulated by food availability (although increased primary production in the first part of the 2014-2016 MHW apparently did not mitigate impact of warming on North American stocks) and other food web effects (redistribution and altered energetics of predators, an area in need of investigation).

\section{REFERENCES}

Abdul-Aziz, O.I., N.J. Mantua, and K.W. Myers. 2011. Potential climate change impacts on thermal habitats of Pacific salmon (Oncorhynchus spp.) in the North Pacific Ocean and adjacent seas. Can. J. Fish. Aquat. Sci. 68(9): 1660-1680.

Behrenfeld, M.J., and P.G. Falkowski. 1997. Photosynthetic rates derived from satellite-based chlorophyll concentration. Limnol. Oceanogr. 42(1): 1-20.

Holte, J., L.D. Talley, J. Gilson, and D. Roemmich. 2017. An Argo mixed layer climatology and database. Geophys. Res. Lett. 44: 5618-5626.

Longhurst, A. 1998. Ecological geography of the sea. Academic Press, San Diego. 398 pp.

Rayner, N.A., D.E. Parker, E.B. Horton, C.K. Folland, L.V. Alexander, D.P. Rowell, E.C. Kent, and A. Kaplan. 2003. Global analyses of sea surface temperature, sea ice, and night marine air temperature since the late nineteenth century. J. Geophys. Res. Vol. 108. No. D14.

Sugihara, G., R. May, H. Ye, C.H. Hsieh, E. Deyle, M. Fogarty, and S. Munch. 2012. Detecting causality in complex ecosystems. Science 338(6106): 496-500.

Ye, H., E.R. Deyle, L.J. Gilarranz, and G. Sugihara. 2015. Distinguishing time-delayed causal interactions using convergent cross mapping. Sci. Rep. 5: 14750. 